DOI: https://doi.org/10.32689/2618-0065-2020-2(4)-32-44

Бобровський Олексій Ілліч, аспірант кафедри державного управління та місцевого самоврядування, Дніпропетровський регіональний інститут державного управління Національної академії державного управління при Президентові України; 49044, м. Дніпро, вул. Гоголя, 29; тел.: (056)794-58-23; e-mail: bobelur@meta.ua; https//orcid.org/ 0000-0001-7395-7477

\title{
ТЕРИТОРІАЛЬНІ ГРОМАДИ ЯК СУБ'ЄКТИ ПУБЛІЧНОГО УПРАВЛІННЯ ПЕРВІСНИХ ТЕРИТОРІАЛЬНИХ ЛАНОК СУСПІЛЬСТВА
}

Анотація. Розглянуто просторовий структурний і елементний склад територіальних громад як сфери застосування нового типу управління публічного, що формується на еволюційному шляху трансформації державного управління та місцевого самоврядування і модернізації органів влади. Доведена необхідність подальшого розвитку інституту публічного управління територіальних громад i пошуку ефективних управлінських моделей. Зазначена необхідність активізації подальших досліджень можливостей, методів і механізмів управління на первісному рівні. Запропонована модель територіальної громади як відкритого об'єкта дослідження публічного управління в місцевому самоврядуванні, яка ілюструє умови побудови процесів життєдіяльності територіальних громад, а саме: необхідні ресурси, призначення їх використання (перелік виробленої продукції і послуг), динаміку їх змін і нарощення за виокремленими напрямами, основні процеси життєдіяльності територіальних громад. Крім того, у моделі підкреслюється необхідність забезпечення конкурентоздатності територіальної громади і спрямованості на підвищення якості життя і зростання ресурсного потенціалу, відображені численні впливи на управління соціальними, економічними та іншими видами розвитку територіальних громад за джерелами їх появи. Як суб’єкт управління територіальна громада представлена у вигляді структурної моделі складників системи публічного управління в середовищі територіальних громад. Модель представлена чотирма блоками і дозволяє отримати уявлення про систему публічного управління територіальних громад, визначити склад, послідовність і методологічне забезпечення управлінської діяльності учасників процесів публічного управління, проаналізувати зв'язки й отримані результати діяльності керованих систем, відшукати існуючі резерви і розробити стратегії їх удосконалення і розвитку. Наведено взаємозв’язки в системі публічного управління територіальних громад створення інституційного посередництва демократизації управління на базовому рівні. 
Запропоновані моделі необхідні для визначення і побудови управлінських зв'язків в системі публічного управління територіальних громад, що створюють умови для юридичних, соціальних, економічних прямих i зворотних зв'язків реалізації суспільних цілей і інтересів жителів територій.

Ключові слова: адміністративно-територіальний устрій, територіальні громади, реформи, децентралізація, публічне управління, органи управління, моделі дослідження територіальних громад.

Bobrovskyi Oleksii Illich, graduate student of the Department of Public Administration and Local Government Dnipropetrovsk Regional Institute of Public Administration of the National Academy of Public Administration, the President of Ukraine; 49044, Dnipro city, Gogol str., 29; тел. (056)794-58-23; e-mail: bobelur@meta.ua; https//orcid.org/ 0000-0001-7395-7477.

\section{TERRITORIAL COMMUNITIES AS SUBJECTS OF PUBLIC ADMINISTRATION OF THE ORIGINAL TERRITORIAL UNITS OF SOCIETY}

Abstract. We examined the spatial structural composition of territorial communities as a sphere of application of a new type of governance, as public, formed on the evolutionary path of transformation of public administration and local self-government and modernization of government, as well as elemental. The necessity of further development of the institute of public administration of territorial communities and the search for effective managerial models is proved. It is noted that, at the initial level, there is a need to intensify further research on the possibilities, methods and management mechanisms. The proposed model of the territorial community, namely: the necessary resources, the purpose of their use (list of products and services), the dynamics of their changes and building up the main processes of the territorial communities as an open research object of public administration in local self-government, which illustrates the conditions for the construction of processes vital activity of territorial communities. In addition, the model emphasizes the need to ensure the competitiveness of the territorial community and focus on improving the quality of life and increasing the resource potential, reflecting the numerous influences on the management of social, economic and other types of development of territorial communities by the sources of their appearance. The territorial community, as a subject of management, is presented in the form of a structural model of the components of the public administration system among the territorial communities. The model is presented in four blocks and allows you to get an idea of the public administration system of territorial communities, to determine the composition, consistency and methodological support of the management activities of participants in public administration processes, analyze the relationships between the results of the activities of managed systems, find the existing reserves 
and develop strategies for their improvement and development. In the public administration system, the interconnections of territorial communities of creating institutional mediation of democratization of management at a basic level are given. The proposed models create the conditions for legal, social, economic direct and feedback links for the implementation of public goals and interests of the residents of the territories, which are necessary for determining and building managerial ties in the public administration system of territorial communities.

Keywords: administrative-territorial structure, territorial communities, reforms, decentralization, public administration, governing bodies, research models of territorial communities.

Постановка проблеми. Визначення територіальних громад як нових суб’єктів управління і надані їм повноваження та завдання зумовили появу нового змісту і джерел управлінського впливу на розвиток суспільних ланок, суспільства в цілому, а отже, сформувало умови для соціально орієнтованої ринкової економіки і трансформації державного управління та місцевого самоврядування в публічне управління. Перші спроби імплементування змісту державного управління в публічне управління засвідчують, що управлінські впливи на суспільні сфери діяльності з боку держави за змістом $є$ публічними і їх можливо розвивати як елементи публічної влади не тільки в державному управлінні, а й у місцевому самоврядуванні. Тому з часом стали розширюватись межі і напрями «публічності» в усіх видах влади.

«Публічність» державного управління і місцевого самоврядування на рівні територіальних громад отримала характерні риси відповідного публічного статусу. Активна легітимізація переходу і надання державному управлінню публічного характеру розпочалася 3 визначення конституційних основ територіальної влади на місцевому рівні та законодавчого закріплення органів виконавчої влади і місцевого самоврядування. Цей процес поглибився 3 прийняттям законів України «Про місцеві державні адміністрації» та «Про державну службу» і Постанови Кабінету Міністрів України «Про затвердження переліку галузей знань і спеціальностей, за якими здійснюється підготовка здобувачів вищої освіти» $[1 ; 2 ; 3]$. Галузь знань «Публічне управління i адміністрування» і відповідні ій освітні спеціальності стали інструментами реального забезпечення публічного управління відповідними фахівцями. Децентралізація влади і ринкові відносини створили умови для суттєвого розширення самостійності та відповідальності територіальних громад як суб'єктів господарювання.

Аналіз останніх досліджень і публікацій. Теоретичні засади появи територіальних громад як самостійних суб'єктів господарювання розглядалися зарубіжними і вітчизняними вченими. Формування територіальних громад як суб'єктів господарювання стало можливим унаслідок появи низки теорій. Уперше наукове обгрунтування феномену громади надали в теорії вільної 
громади (теорії природних прав громади) А. Токвіль та його послідовники. Автори теорії наголошували, що поряд із законодавчою, виконавчою та судовою владою повинна існувати і громадівська (муніципальна) влада. Згідно 3 наступною господарською теорією (громадсько-господарською) органи місцевого самоврядування не є державними, вони мають виняткове право на задоволення потреб громади в неполітичній (економічній, соціальній, культурній) сфері, вирішуючи місцеві проблеми, які мають недержавний характер, зробивши акцент на змісті комунальної діяльності. Зазначені теорії набули свого узагальнення і розвитку в громадській (громадівській) теорії місцевого самоврядування, яка вбачала сутність самоврядування в наданні місцевій спільноті можливості самостійно реалізовувати свої громадські інтереси та зберігала за урядовими органами відання тільки державними справами [4]. У процесі розбудови України, як демократичної держави територіальні громади були визначені як самостійний суб'єкт господарювання $[1 ; 3 ; 5 ; 6 ; 7 ; 8]$. Зазначаючи широту поглиблення уваги до теоретичних i законодавчо-нормативних засад становлення самостійності територіальних громад як суб'єктів місцевого самоврядування і визначення їх юридичного статусу, слід підкреслити, що питання забезпечення організації їх діяльності вирішуються вкрай повільно, що мотивує до активізації подальших досліджень практичної спрямованості.

Дослідження питань місцевого самоврядування та статусу територіальних громад розглядаються в працях багатьох українських учених: М. О. Баймуратова, О. В. Батанова, В. І. Борденюка, В. Ф. Погорілка, В. М. Кампо, В. В. Кравченко, В. С. Куйбіди, М. П. Орзіха, М. О. Пухтинського, О. В. Фрицького та багатьох ін. $[4 ; 9 ; 10 ; 11 ; 12]$. Але складність становлення дієздатних, ефективно функціонуючих територіальних громад і швидкість трансформаційних змін у процесах життєдіяльності України мотивує до продовження досліджень проблемних питань організації, ефективного функціонування та підвищення ролі громад у процесах суспільного розвитку.

Мета статті: розглянути територіальні громади як суб'єкти публічного управління у власному територіальному просторі, що формується під впливом демократичних змін державного управління, визначити об’єктні складники управління в середовищі дій і впливів публічного управління, обгрунтувати вектори подальшого дослідження розвитку територіальних громад як самостійних суб’єктів публічного управління на публічному рівні.

Виклад основного матеріалу. Територіальні громади - це територіальні системи господарювання, зорієнтовані на позитивну динаміку параметрів рівня і якості життя населення шляхом забезпечення сталого, збалансованого ресурсного і господарського потенціалу. Як суб'єкти господарювання територіальні громади мають право на розпорядження значною частиною національного багатства, вони інтегруються в загальнодержавну економіку, 
залучаються до конкурування за інвестиції, кваліфіковані робочі місця, за якісне життя своїх громадян.

Позитивна динаміка економічного життя створює громадам максимально сприятливі умови для залучення капіталу i фінансових ресурсів, надає можливості стати сучасними формами просторової взаємодії і бути органом територіального підприємництва (як продавець ресурсів, товарів, продукції). Територіальні громади згідно із законом України «Про місцеве самоврядування» [7] являють собою органи суспільних ланок територій різних рівнів, які обираються жителями на основі загального, рівного і прямого виборчого права. Їх повноваженнями і обов'язками стає розгляд проектів програм соціально-економічного розвитку місцевих бюджетів, розробка проектів рішень стосовно розвитку господарського і культурного виробництва, здійснення висновків стосовно регулюючого стану територіальних громад, підготовка рекомендацій і контроль за реалізацією розроблених заходів та координація діяльності відповідальних служб.

За адміністративно-територіальним поділом система публічного управління має таку ієрархію: держава - область - місто - райони в місті райони - села і селища. Органи державної влади на місцевому рівні в організаційному плані являють собою різноманітні організаційні форми і типи місцевої демократії, через які здійснюються їх функціональні повноваження, що дозволяє розглядати їх як невід’ємні складники публічного управління. Органи місцевого самоврядування не входять в систему органів державної влади, оскільки в їх повноваженнях відсутня основна ознака держави прийняття законів, хоча в частковому забезпеченні функції району вона присутня.

Головними адміністративними структурами, які виконують адміністрування територій є органи виконавчої влади, які в більшості країн називають органами публічної влади. При цьому розділяють чотири основні різновиди публічної влади:

- політична недержавна влада муніципального рівня (муніципальні колективи);

- міжнародна публічна влада міжнародного співтовариства,міждержавна влада, в якій беруть участь усі суверенні держави,наприклад рада безпеки ООН;

- політика, політична недержавна влада - автономні утворення, які приймають власні закони;

- публічна влада громадських об’єднань.

Публічно-територіальні колективи розглядаються органом, застосовуваним державою і суспільством тієї чи іншої країни. Оскільки поняття муніципалітету в Україні не вживається, то як публічні колективи розглядаються територіальні громади. На міжнародному рівні також існують територіальні публічні колективи $(\mathrm{OOH}$, Рада безпеки, в Свросоюзі - 
Євпропарламент, організація Африканської єдності арабських держав тощо). Усі ці організаційні структури наділяються владою наддержавною або недержавною. Їх основне призначення $\epsilon$ організація виконання законів i правових актів, у чому і проявляється публічне управління.

Аналізуючи процес формування публічного управління в Україні, можемо виділити такі його етапи:

1.1997 - 2014 рр. - період розуміння необхідності ліквідування радянського жорстко адміністративного управління державними справами, безальтернативність побудови нового типу управління, опанування знань i набуття досвіду управління прогресивних західних країн. На цьому етапі здійснювався вибір комунікативних засобів і відносин органів влади, населення і господарюючих суб'єктів, переглядався зміст діяльності інституціальних засобів влади, виокремлювалися спільні інтереси влади і населення та вирішувалося багато інших проблем державотворення в незалежній, соціально орієнтованій, ринково спрямованій країни господарювання. Цей період навряд чи можна вважати продуктивним. Зміна типу економіки супроводжувалася втратою темпів зростання соціальноекономічних результатів, погіршенням життя населення України, руйнуванням промислового комплексу, неякісним використанням сільськогосподарського потенціалу. На погіршення економічних і соціальних умов життя в Україні суттєво вплинули агресивні дії Росії, політичні обставини і неефективні заходи для їх призупинення. Однак, незважаючи на негативні чинники й обставини загублення міцності держави, продовжували нарощуватись паростки певного розвитку в системі державного управління, перетворення в органах державної і місцевої влади.

2. Кінець 2014 - 2018 рp. - реформування і активні зміни існуючого законодавства (внесення змін до Бюджетного та Податкового кодексу [13; 14]; Закон України «Про добровільне об’єднання територіальних громад» [15], який запровадив інститут старост об'єднаних територіальних громад; закони України «Про співробітництво територіальних громад» [8], «Про засади державної регіональної політики» [16] і пакет внесення змін до деяких законодавчих актів України щодо розширення повноважень органів місцевого самоврядування та оптимізації надання адміністративних послуг [6] та ін.), що значно посилило можливості міжмуніципальної консолідації в Україні і створило належні правові умови для формування механізмів підвищення публічності місцевого самоврядування територіальних громад.

3.2019 - 2020 pр. - прийняття низки законодавчих актів про прискорення реформ у сфері охорони здоров'я, освіти, культури, соціальних послуг та енергоефективності. Новий етап реформ децентралізації створив умови чіткого розмежування повноважень та функцій контролю різних рівнів органів управління і подальший розвиток місцевої демократії.

Отже, можемо засвідчити суттєвий зсув центру тяжіння стосовно 
демократизації влади на рівень територіальних громад. Це сприяло появі нових імпульсів розвитку публічного управління на цьому рівні. Суттєві обмеження і функції адміністрування посилили соціальні та демократичні основи, створивши в територіальних громадах передумови поєднання публічності всіх гілок влади. Сформувалося нове ставлення до всіх процесів життєдіяльності суспільства і їх результатів без жорсткого адміністрування і якомога глибшої демократії в його побудові. Система публічного управління територіальних громад стала розглядатись як єдність соціальних, економічних, екологічних, технічних, культурних та інших право-суб'єктних і суспільних структур управління з процесами їх життєдіяльності в просторі територіальних громад.

Водночас слід підкреслити, що територіальні громади як об'єкт публічного управління, враховуючи порівняно короткий період часу з початку модернізації і децентралізації державної влади, ще не є достатньо дослідженими, а органи місцевого самоврядування і жителі як суб' єкти публічного управління ще повністю не оволоділи мистецтвом управління в нових умовах господарювання. До того ж публічне управління постійно реформується відповідно до зростаючих потреб розвитку. Тому дослідження територіальних громад як об’єкта публічного управління, джерела та інструменту впливу на іiі розвиток на сучасному етапі слід розглядати як ключовий напрям підвищення їх здатності до вирішення власних справ на шляху інноваційної трансформації. У зв'язку із цим необхідно продовжувати дослідження особливостей і специфіки територіальних громад 3 метою поглиблення і зміцнення методичного, інструментально-технологічного забезпечення i концептуалізації шляхів їх подальшої розвитку.

Для розгляду просторового структурного i змістовного складу територіальних громад представимо їх як суб'єкт господарювання у вигляді моделі територіальної громади як відкритого об’єкта дослідження публічного управління в місцевому самоврядуванні (рис. 1). 


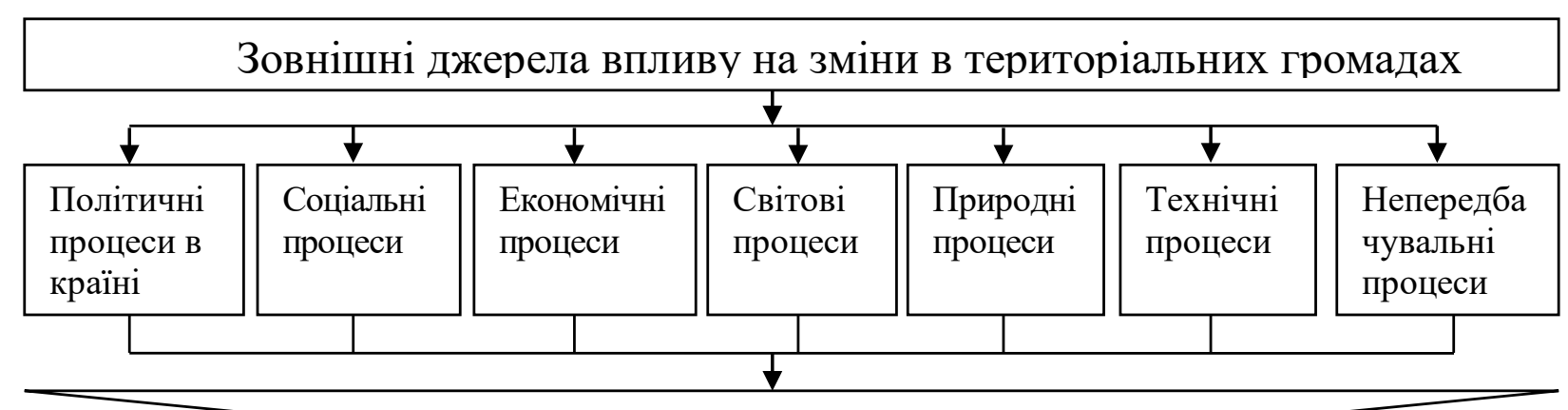

\begin{tabular}{l|l}
$\begin{array}{l}\text { - Природні ресурси; } \\
\text { - трудові ресурси; } \\
\text { - фінансові ресурси; } \\
\text { - земельні ресурси; } \\
\text { - інфраструктурні } \\
\text { ресурси; } \\
\text { - підприємницькі } \\
\text { ресурси; } \\
\text {-науково-технічні } \\
\text { ресурси та ін. }\end{array}$ \\
\hline $\begin{array}{l}\text { Система публічного } \\
\text { управління територіальних } \\
\text { громад-єдність соціальних, } \\
\text { економічних, екологічних, } \\
\text { технічних, культурних та } \\
\text { інших правосуб’єктни і } \\
\text { суспільних відносин, владних } \\
\text { і суспільних структур } \\
\text { управління процесами } \\
\text { життєдіяльності }\end{array}$ \\
\hline Конкурентоспроможність \\
\hline Відвищення якості життя \\
\hline Відновлення і зростання \\
\hline
\end{tabular}

Рис. 1. Модель територіальної громади як відкритого об'єкта дослідження публічного управління в місцевому самоврядуванні

Модель ілюструє умови побудови процесів життєдіяльності територіальних громад, а саме: необхідні ресурси, призначення їх використання (перелік виробленої продукції і послуг), динаміку їх змін і нарощення за виокремленими напрямами, основні процеси життєдіяльності територіальних громад. Крім того, у моделі підкреслюється необхідність забезпечення конкурентоздатності територіальної громади і спрямованості на підвищення якості життя і зростання ресурсного потенціалу, відображені численні впливи на управління соціальними, економічними та іншими видами розвитку територіальних громад за джерелами їх появи. Вона $\epsilon$ моделлю просторового структурного і елементного стану територіальних громад як системи управління, що дозволить дослідити особливості побудови і функціонування системи публічного управління на цьому рівні, напрями й види управлінських відносин і управлінських впливів 3 усіма їх складниками; дозволить описати публічне управління в термінах галузей 
знань, які акумулюються в теорію публічного управління, уточнити і розвинути понятійний апарат, визначити зміст і послідовність виконання функцій і завдань, уявити територіальні громади як відкритий складний об’єкт управління, виявити напрями впливів в умовах зміни навколишнього середовища.

Відкритість системи територіальних громад, вхідна і вихідна інформація, множина обставин (умов), в яких відбуваються процеси життєдіяльності і розвитку територіальних громад, показують, що як системи вони належать до дискретних динамічних моделей. При незмінюваному просторі існування територіальні громади можуть змінювати внутрішні зв'язки, зв'язки 3 навколишнім середовищем, впливати на причини і наслідки свого існування.

Як суб’єкт управління територіальна громада представлена у вигляді структурної моделі складників системи публічного управління в середовищі територіальних громад (рис. 2).

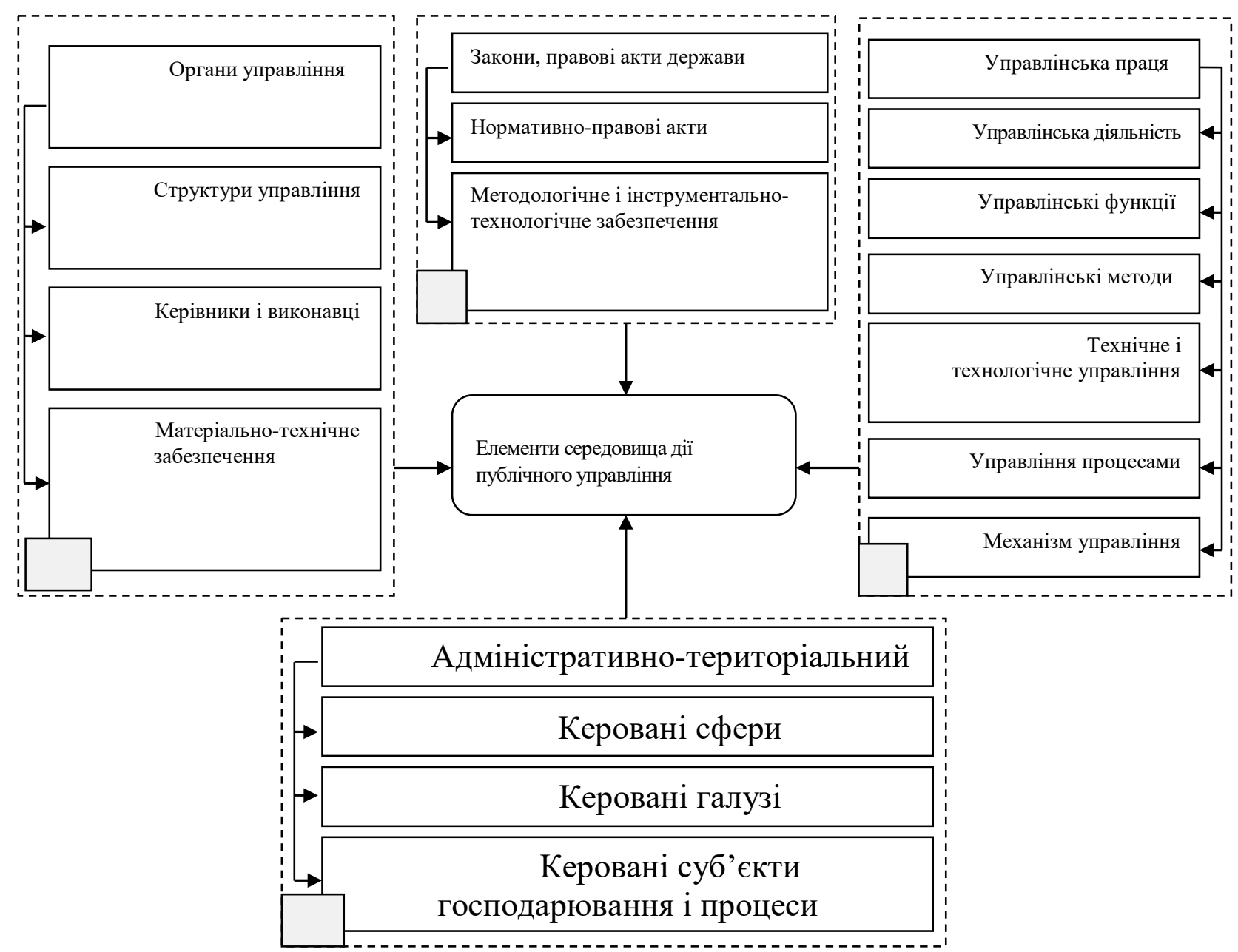

Рис. 2. Структурна модель складників системи публічного управління в середовищі територіальних громад

\footnotetext{
I - нормативно-законодавчий блок

II - управлінський структурно-елементний блок

III - блок діяльнісно-продуктивний

IV - блок керованих суб'єкто-об'єктів
} 
Модель представлена чотирма блоками: нормативно-законодавчий, управлінський структурно-елементний, діяльнісно-продуктивний i блок керованих об’єкто-суб’єктів. Модель дозволяє отримати уявлення про систему публічного управління територіальних громад, визначити склад, послідовність, зв'язки і методологічне забезпечення управлінської діяльності учасників процесів публічного управління, проаналізувати зв'язки й отримані результати діяльності керованих систем, відшукати існуючі резерви і розробити стратегії їх удосконалення і розвитку.

На сучасному етапі територіальні громади слід розглядати не тільки як одиниці адміністративно-територіального устрою, а як нову територіальну організацію влади, як систему управління демократичними перетвореннями в суспільному управлінні. Публічне управління на рівні територіальних громад повинно враховувати їх системні особливості. Питома вага структурних елементів публічного управління в місцевому самоврядуванні і державному управлінні збільшується. Вони формуються залежно від особливостей територіальних громад, цілей і умов їх розвитку, ресурсів і потреб жителів, впливаючи на їх розвиток демократичними методами і застосовуючи нові механізми суспільного цивілізаційного розвитку.

Територіальні громади як самостійний суб'єкт управління, їх цілі, завдання, функції, технології і механізми на сучасному етапі розвитку України ще недостатньо відпрацьовані, вони є безсистемними і не завжди своєчасними. Але, на жаль, в плані заходів з виконання Програми діяльності Кабінету Міністрів України та Стратегії сталого розвитку «Україна - 2020», прийнятій у 2015 р. [17], заходи щодо системного здійснення організаційних нововведень у систему публічного управління територіальних громад для ефективної реалізації прийнятих стратегічних завдань стосовно якісного управління суспільними змінами на цьому рівні не запропоновані. Зазначене мотивує до продовження теоретичних досліджень територіальних громад як суб’єктів управління з метою їх практичного удосконалення.

Висновки. Децентралізація державної влади в Україні створила умови для дієздатності і самостійності територіальних громад, тобто реального місцевого самоврядування як провідного інституту громадянського суспільства. Як базова ланка суспільства територіальна громада стає первісним суб'єктом і основним носієм функцій публічного управління, повноваження і відповідальність якої формуються на природних, соціальних, економічних $\mathrm{i}$ екологічних ознаках. На рівні територіальних громад формуються права i відповідальність жителів у сфері самоврядування, які спрямовуються на забезпечення місцевих потреб.

Для глибокого розуміння і раціонального застосування можливостей територіальної громади як суб'єкто-об'єкта необхідним стає дослідження іiі нових функцій, методів і засобів вирішення місцевих проблем. Необхідність 
ефективного функціонування територіально-адміністративних ланок конституційного ладу суспільства обумовлює аналіз суб’єктно-об’єктного складу територіальних громад i необхідність продовження грунтовних досліджень методологічного, організаційного, інструментального забезпечення здійснення їх самоврядної діяльності й управління розвитком. Системоутворюючими чинниками територіальних громад є стійкі економічні, соціальні, інформаційні, політичні, культурні, екологічні зв’язки і відносини, які формують самостійну систему просторової організації життєдіяльності людей.

Запропоновані моделі територіальної громади як об’єкта i суб’єкта управління необхідні для визначення і побудови управлінських зв’язків в системі публічного управління територіальних громад, що створюють умови для юридичних, соціальних, економічних прямих і зворотних зв’язків реалізації суспільних цілей і інтересів жителів територій. Публічне управління розвитком територіальної громади як особливої форми соціальної діяльності базується на принципах субсидіарності, суверенності, демократизму.

\section{Лimepamypa:}

1. Про державну службу : Закон України від 10 груд. 2015 р. № 889-VIII. - Режим доступу : https://zakon.rada.gov.ua/laws/show/889-19.

2. Про затвердження переліку галузей знань і спеціальностей, за якими здійснюється підготовка здобувачів вищої освіти : Постанова Кабінету Міністрів України від 29 квіт. 2015 p. № 266. - Режим доступу : https://zakon.rada.gov.ua/laws/show/ru/266-2015-п.

3. Про місцеві державні адміністрації : Закон України від 9 квіт. 1999 р. № 586-XIV. Режим доступу : https://zakon.rada.gov.ua/laws/show/586-14.

4. Остапенко О.Г. Територіальні громади як первинний суб’єкт місцевого самоврядування та реалізації муніципальної політики / Остапенко О. Г., Барановська Т. М. // Державне управління: удосконалення та розвиток. - 2015. - № 10. - Режим доступу: http://www.dy.nayka.com.ua/pdf/10_2015/9.pdf.

5. Конституція України від 28 червня 1996 р. - Режим доступу : https://zakon.rada.gov.ua/laws/show/254к/96-вр.

6. Про внесення змін до деяких законодавчих актів України щодо розширення повноважень органів місцевого самоврядування та оптимізації надання адміністративних послуг : Закон України від 10 груд. 2015 р. № 888-VIII. - Режим доступу : https://zakon.rada.gov.ua/laws/show/888-19.

7. Про місцеве самоврядування : закон України від 21 трав. 1997 р. №280/97-ВР. Режим доступу : https://zakon.rada.gov.ua/laws/show/280/97-вр.

8. Про співробітництво територіальних громад : Закон України від 17 черв. 2014 р. № 1508-VII. - Режим доступу : https://zakon.rada.gov.ua/laws/show/1508-18.

9. Беймуратов М. О. Територіальна громада в політичній і системі місцевого самоврядування України // Муніципальне право України : підручник / В. Ф. Погорілко, О. Ф. Фрицький, М. О. Баймуратов [та ін.] ; за ред В. Ф. Погорілка, О. Ф. Фрицького. Київ : Юрінком Інтер, 2001. - 352 с.

10. Глухачов С. Ф. Місцеве самоврядування в Україні: особливості його правової природи / Є. Ф. Глухачев // Актуальні проблеми державного управління : наук. зб. - Харків : УАДУ (ХФ). - 2001. - № 1(9). - С. 42 - 43. 
11. Актуальні проблеми становлення та розвитку місцевого самоврядування в Україні : кол. монографія / за ред. В. В. Кравченка, М. О. Беймуратова, О. В. Батанова. - К. : Атіка, 2007. - 864 с.

12. Батанов О. В. Територіальна громада - первинний суб’єкт муніципальної влади в Україні: поняття та ознаки / О. В. Батанов // Вісник Центральної виборчої комісії. - 2008. - № 2. - С. $51-57$.

13. Бюджетний кодекс України від 8 липня 2010 р. № 2456-VI. - Режим доступу : https://zakon.rada.gov.ua/laws/show/2456-17.

14. Податковий кодекс України від 2 грудня 2010 р. № 2755-VI. - Режим доступу : https://zakon.rada.gov.ua/laws/show/2755-17.

15. Про добровільне об’єднання територіальних громад : Закон України від 5 лют. 2015 p. № 157-VIII. - Режим доступу : https://zakon.rada.gov.ua/laws/show/157-19.

16. Про засади державної регіональної політики : Закон України 5 лют. 2015 р. № 156VIII. - Режим доступу : https://zakon.rada.gov.ua/laws/show/156-19.

17. Про затвердження плану заходів 3 виконання Програми діяльності Кабінету Міністрів України та Стратегії сталого розвитку «Україна - 2020» у 2015 р. : розпорядження Кабінету Міністрів України від 4 берез. 2015 р. № 213-р. - Режим доступу : https://zakon.rada.gov.ua/laws/show/21.

\section{References:}

1. Zakon Ukrainy «Pro derzhavnu sluzhbu» [The Law of Ukraine «About the civil service»]. (n.d.). zakon.rada.gov.ua. Retrieved from https://zakon.rada.gov.ua/laws/show/889-19 [in Ukrainian].

2. Postanova Kabinetu Ministriv Ukrainy «Pro zatverdzhennia pereliku haluzej znan’ i spetsial'nostej, za iakymy zdijsniuiet'sia pidhotovka zdobuvachiv vyschoi osvity» [Resolution of the Cabinet of Ministers of Ukraine «On approval of the list of branches of knowledge and specialties by which higher education applicants are trained»]. (n.d.). zakon.rada.gov.ua. Retrieved from https://zakon.rada.gov.ua/laws/show/ru/266-2015-p [in Ukrainian].

3. Zakon Ukrainy «Pro mistsevi derzhavni administratsii» [The Law of Ukraine «About local state administrations»]. (n.d.). zakon.rada.gov.ua. Retrieved from https://zakon.rada.gov.ua/laws/show/586-14 [in Ukrainian].

4. Ostapenko, O. H. \& Baranovs’ka, T. M. (2015). Terytorial’ni hromady iak pervynnyj sub'iekt mistsevoho samovriaduvannia ta realizatsii munitsypal'noi polityky [Territorial communities as the primary subject of local self-government and implementation of municipal policy]. Derzhavne upravlinnia: udoskonalennia ta rozvytok. - Public Administration: Improvement and Development, $10 . \quad$ Retrieved from http://www.dy.nayka.com.ua/pdf/10_2015/9.pdf [in Ukrainian].

5. «Konstytutsiia Ukrainy» [«Constitution of Ukraine»]. (n.d.). zakon.rada.gov.ua. Retrieved from https://zakon.rada.gov.ua/laws/show/254k/96-vr [in Ukrainian].

6. Zakon Ukrainy «Pro vnesennia zmin do deiakykh zakonodavchykh aktiv Ukrainy schodo rozshyrennia povnovazhen' orhaniv mistsevoho samovriaduvannia ta optymizatsii nadannia administratyvnykh posluh» [The Law of Ukraine «On Amendments to Some Legislative Acts of Ukraine on Expanding the Authorities of Local Self-Government Bodies and Optimizing the Provision of Administrative Services»]. (n.d.). zakon.rada.gov.ua. Retrieved from https://zakon.rada.gov.ua/laws/show/888-19 [in Ukrainian].

7. Zakon Ukrainy «Pro mistseve samovriaduvannia» [The Law of Ukraine «About local government»]. (n.d.). zakon.rada.gov.ua. Retrieved https://zakon.rada.gov.ua/laws/show/280/97-vr [in Ukrainian]. 
8. Zakon Ukrainy «Pro spivrobitnytstvo terytorial'nykh hromad» [The Law of Ukraine «On cooperation of territorial communities»]. (n.d.). zakon.rada.gov.ua. Retrieved from https://zakon.rada.gov.ua/laws/show/1508-18 [in Ukrainian].

9. Pohorilko, V. F., Fryts'kyj, O. F. \& Bajmuratov, M. O. (2001). Terytorial'na hromada v politychnij i systemi mistsevoho samovriaduvannia Ukrainy [Territorial community in the political and local self-government system of Ukraine]. Munitsypal'ne pravo Ukrainy - Municipal Law of Ukraine (p. 352). Kyiv: Yurinkom Inter [in Ukrainian].

10. Hlukhachov, Ye. F. (2001). Mistseve samovriaduvannia v Ukraini: osoblyvosti joho pravovoi pryrody [Local self-government in Ukraine: features of its legal nature]. Aktual'ni problemy derzhavnoho upravlinnia - Actual problems of public administration, 1(9), 42 - 43 [in Ukrainian].

11. Kravchenka, V. V., Bejmuratova, M. O. \& Batanova, O. V. (2007). Aktual'ni problemy stanovlennia ta rozvytku mistsevoho samovriaduvannia $v$ Ukraini [Actual problems of formation and development of local self-government in Ukraine]. Kyiv: Atika [in Ukrainian].

12. Batanov, O. V. (2008). Terytorial'na hromada - pervynnyj sub’iekt munitsypal’noi vlady v Ukraini: poniattia ta oznaky [Territorial community - the primary subject of municipal government in Ukraine: concepts and features]. Visnyk Tsentral'noi vyborchoi komisii - Bulletin of the Central Election Commission, 2, 51 - 57 [in Ukrainian].

13. «Biudzhetnyj kodeks Ukrainy» [«Budget Code of Ukraine»]. (n.d.). zakon.rada.gov.ua. Retrieved from https://zakon.rada.gov.ua/laws/show/2456-17 [in Ukrainian].

14. «Podatkovyj kodeks Ukrainy» [«Tax Code of Ukraine»]. (n.d.). zakon.rada.gov.ua. Retrieved from https://zakon.rada.gov.ua/laws/show/2755-17 [in Ukrainian].

15. Zakon Ukrainy «Pro dobrovil'ne ob'iednannia terytorial'nykh hromad» [The Law of Ukraine «About voluntary association of territorial communities»]. (n.d.). zakon.rada.gov.ua. Retrieved from https://zakon.rada.gov.ua/laws/show/157-19 [in Ukrainian].

16. Zakon Ukrainy «Pro zasady derzhavnoi rehional'noi polityky» [The Law of Ukraine «On the principles of state regional policy»]. (n.d.). zakon.rada.gov.ua. Retrieved from https://zakon.rada.gov.ua/laws/show/156-19 [in Ukrainian].

17. Rozporiadzhennia Kabinetu Ministriv Ukrainy «Pro zatverdzhennia planu zakhodiv z vykonannia Prohramy diial'nosti Kabinetu Ministriv Ukrainy ta Stratehii staloho rozvytku «Ukraina - 2020» u 2015 r.» [Order of the Cabinet of Ministers of Ukraine «On approval of the action plan for the implementation of the Program of Activities of the Cabinet of Ministers of Ukraine and the Sustainable Development Strategy "Ukraine 2020" in 2015»]. (n.d.). zakon.rada.gov.ua. Retrieved from https://zakon.rada.gov.ua/laws/show/21 [in Ukrainian]. 